\title{
A Facile Method for the Labeling of Proteins with Zirconium Isotopes
}

\author{
Wilma E. Meijs, ${ }^{1 *}$ Hidde J. Haisma, ${ }^{2}$ \\ Roel Van Der Schors, ${ }^{3}$ René Wijbrandts, ${ }^{1}$ Karin Van Den Oever, ${ }^{1}$ \\ Rob P. Klok, ${ }^{1}$ Herbert M. Pinedo ${ }^{2}$ and Jacobus D. M. Herscheid ${ }^{1}$ \\ ${ }^{1}$ RADIONUCLIDECENTRE, FREE UNIVERSITY, ${ }^{2}$ DEPARTMENT OF ONCOLOGY, FREE UNIVERSITY HOSPITAL, AND \\ ${ }^{3}$ GRADUATE SCHOOL NEUROSCIENCES AMSTERDAM, FREE UNIVERSITY, AMSTERDAM, THE NETHERLANDS
}

\begin{abstract}
ABSTRAC'T. To label proteins with positron emitters with a half-life in the order of days, a method has been developed to label proteins with zirconium $\left(\mathrm{Z}_{\mathrm{r}}\right)$-isotopes. Therefore, the bifunctional chelating agent desferal (Df) was coupled to albumins via a thioether bond. Labeling of the premodified proteins was easily performed by addition of these proteins to freeze-dried $\mathrm{Zr}$-oxalate. This labeling was efficient $(>90 \%)$ and accomplished in several minutes. The conjugates showed a high in vitro stability. Biodistribution studies were performed with ${ }^{88} \mathrm{Zr}$-citrate, ${ }^{88} \mathrm{Zr}$-Df, and ${ }^{88} \mathrm{Zr}$-labeled mouse serum albumin $\left({ }^{88} \mathrm{Zr}\right.$-Df-MSA), modified with different amounts of chelating groups. Whereas $\mathrm{Z}_{r}$-citrate was found to accumulate in bone, $\mathrm{Z}_{\mathbf{r}}$-Df was cleared very fast by glomerular filtration. The ${ }^{88} \mathrm{Zr}$-Df-MSA showed similar blood clearance as did ${ }^{123}$ I-labeled MSA. The biodistribution pattern of ${ }^{88} \mathrm{Zr}$-Df-MSA differed only from ${ }^{123} \mathrm{I}-\mathrm{MSA}$ in that a higher accumulation of $\mathrm{Zr}$ in liver, kidney, and spleen was found. The absence of large amounts of ${ }^{88} \mathrm{Zr}$ in bone indicated that in vivo the conjugates are also reasonably stable. NUCL MED BIOL 23;4:439-448, 1996.
\end{abstract}

KEY WORDS. Zirconium-89, Zirconium-88, Desferal, Protein labeling

\section{INTRODUCTION}

Positron emission tomography (PET) is a noninvasive imaging technique that provides quantitative data on the biodistribution of radiolabeled compounds. A method to label proteins with positron emitting nuclides might be valuable, considering the ubiquitousness of proteins and peptides and their role in many disease processes. To be useful, the positron emitter must fulfill several requirements. Its production must be simple and inexpensive, and it should not give off radionuclidic impurities. The radionuclide should by preference have a high percentage of positron emission as the only form of decay.

Proteins have been labeled with several positron-emitting isotopes such as ${ }^{18} \mathrm{~F}\left(t_{1 / 2}=110 \mathrm{~min} ; 7,13,31\right),{ }^{68} \mathrm{Ga}\left(t_{1 / 2}=68 \mathrm{~min} ; 31\right)$, ${ }^{64} \mathrm{Cu}\left(t_{1 / 2}=12.7 \mathrm{~h} ; 20,25,32\right)$, and ${ }^{55} \mathrm{Co}\left(t_{1 / 2}=17.5 \mathrm{~h} ; 22,37\right)$. However, the short half-lives of these isotopes hamper the use for the long-term determination of the kinetics and biodistribution of proteins. For instance, they are less suitable for quantitating the biodistribution of monoclonal antibodies (MAb) in order to generate accurate dosimetric data necessary for radioimmunotherapy. The positron emitter ${ }^{89} \mathrm{Zr}\left(t_{1 / 2}=78.4 \mathrm{~h}\right)$ has an appropriate half-life. Although this positron emitter does not fulfill all prerequisites--for instance, it decays for only $23 \%$ by positron emission and has accompanying $\gamma$-radiation--the suitable half-life justifies the choice for this isotope. ${ }^{89} \mathrm{Zr}$ can be produced on ${ }^{89} \mathrm{Y}(100 \%$ natural abundance, $3,18,41$ ) in high yield and a high (radio)chemical purity (24). Although ${ }^{89} \mathrm{Zr}$ seems to be a suitable candidate, until now

\footnotetext{
*Address correspondence to: W. E. Meijs, RadioNuclideCentre, Free University, De Boelelaan 1085c, 1081 HV Amsterdam, The Netherlands.

Accepted 15 January 1996.
}

little effort has been made to label proteins with this isotope. Here we describe the development of a simple and efficient method to label proteins with $\mathrm{Zr}$-isotopes, using albumins as model.

\section{MATERIALS AND METHODS Materials}

Desferal (Df) was obtained from Ciba-Geigy (Basel, Switzerland). $\mathrm{N}$-succinimidyl S-acetylthioacetate (SATA), succinimidyl 4-(Nmaleimidomethyl)cyclohexane-1-carboxylate (SMCC), and iodogen were obtained from Pierce (Rockford, IL). Oxalic acid, sodium hydroxide, hydroxylamine, sodium citrate, and sodium phosphate $\left(\mathrm{Na}_{2} \mathrm{HPO}_{4} \cdot 12 \mathrm{H}_{2} \mathrm{O}\right.$ and $\left.\mathrm{NaH}_{2} \mathrm{PO}_{4} \cdot \mathrm{H}_{2} \mathrm{O}\right)$ were from Merck (Darmstadt, Germany). Ammonium acetate, $n$-butanol, hydrochloric acid, acetic acid, and sodium azide were obtained from J.T. Baker Chemicals BV (Deventer, The Netherlands) and iron(III)chloride was from Aldrich (Borhem, Belgium). Bovine serum albumin (BSA), mouse serum albumin (MSA), and 5,5'-dithio-bis-2nitrobenzoic acid (Ellman's reagent) were from Sigma (St. Louis, $\mathrm{MO}$ ) and mercaptoethanol was from LKB (Bromma, Sweden). BALB/c mice were obtained from Harlan CPB (Zeist, The Netherlands). The ${ }^{88} \mathrm{Zr}$, used as tracer instead of ${ }^{89} \mathrm{Zr}$ because of its more convenient half-life ( $t_{1 / 2}=83.4$ days), was produced as described by Meijs et al. (24). The ${ }^{123}$ I was produced by the $(p, 2 n)$ reaction on $99.98 \%$-enriched ${ }^{124} \mathrm{Xe}\left({ }^{124} \mathrm{Xe}(p, 2 n)^{123} \mathrm{Cs} \rightarrow{ }^{123} \mathrm{Xe} \rightarrow{ }^{123} \mathrm{I}\right)$. Ultrapure water was used throughout the experiments to minimize the amount of metal impurities in the solutions.

\section{General Procedures}

After labeling, the proteins were analyzed by instant thin layer chromatography (ITLC) and thin layer chromatography (TLC). 
The ITLC was performed on silica-gel-impregnated glass fiber sheets (Gelman Sciences Inc., Ann Arbor, MI) with $0.5 \mathrm{M}$ sodium citrate $(\mathrm{pH}=4.5)$ as mobile phase. The TLC was performed on aluminum-backed cellulose plates (Merck, Darmstadt, Germany); $n$-butanol/water/acetic acid (2/1/1) was used as mobile phase. After elution, the plates were cut into 10 pieces and assayed for radioactivity using a 1282 Compugamma counter (Wallac, Turku, Finland).

Gel filtration was performed on G-25 (PD-10-columns) and G-50 using a $0.1 \mathrm{M}$ acetate buffer $(\mathrm{pH}=6)$ as eluent, unless described otherwise. The G-25 and G-50 gel filtration column materials were from Pharmacia Biotech (Roosendaal, The Netherlands).

High-performance liquid chromatography (HPLC) was performed on a Protein Pak 300 SW column (Waters, Milford, MA) using a Pharmacia HPLC-pump (2150). Ammonium acetate $(0.2$ $\mathrm{M}, \mathrm{pH}=6.5)$ containing $0.05 \%$ sodium azide was used as eluent (flow rate $0.5 \mathrm{~mL} / \mathrm{min}$ ). A UV-detector (Pharmacia, Uppsala, Sweden) at $280 \mathrm{~nm}$ and a flow-through radioactivity detector (Ortec $406 \mathrm{~A}$ single-channel analyzer) were used to monitor the eluate.

\section{"Direct Labeling" of Bovine Serum Albumin with ${ }^{88} \mathrm{Zr}\left({ }^{88} \mathrm{Zr}\right.$-BSA)}

The ${ }^{88} \mathrm{Zr}$ was isolated in oxalic acid with a hydroxamate-column as described by Meijs et al. (24). The oxalic acid was removed by sublimation at room temperature in vacuo. BSA $(100 \mu \mathrm{g})$ in $100 \mu \mathrm{L}$ of either $0.1 \mathrm{M}$ acetate buffer ( $\mathrm{pH}=5$ and 6 ) or $0.1 \mathrm{M}$ citrate buffer $(\mathrm{pH}=5$ and 6 ) was added to this freeze-dried $\mathrm{Zr}$-oxalate. After $1 \mathrm{~h}$ of incubation the protein was analyzed by G-50 gel filtration and ITLC.

\section{N-(S-acetyl)Mercaptoacetyldesferal (SATA-Df)}

SATA-Df (Scheme 1) was prepared by dissolving Df $(0.473 \mathrm{mmol})$ in $10 \mathrm{~mL}$ of water. The $\mathrm{pH}$ was adjusted to 9 using $1 \mathrm{M} \mathrm{NaOH}$. SATA $(0.179 \mathrm{mmol})$ was added and the reaction mixture was allowed to stand at room temperature for $2 \mathrm{~h}$. Hereafter, the solution was acidified to $\mathrm{pH}=2$ using concentrated $\mathrm{HCl}$, resulting in precipitation of SATA-Df, while unreacted Df remained in the solution. Recrystallization from $10 \mathrm{~mL}$ of $1 \mathrm{mM} \mathrm{HCl}$ yielded 0.139 mmol SATA-Df (78\%). The product was analyzed by TLC and mass spectrometry (Finnigan MAT90, Bremen, Germany). Silicaplates (DC Alufolien from Merck, Darmstadt, Germany) were used for the TLC analysis. Spots were eluted with $\mathrm{MeOH}$ and detected by spraying with $1 \% \mathrm{FeCl}_{3}$; the product was found to have an $\mathrm{R} f$-value of 0.65 , while $\mathrm{Df}$ remained at the origin. MS-results: (Df$\left.\mathrm{NH}-\mathrm{CH}_{2}-\mathrm{S}-\mathrm{C}(\mathrm{O})-\mathrm{CH}_{3}\right) \mathrm{H}^{+}=677(4 \%),\left(\mathrm{Df}-\mathrm{NH}-\mathrm{CH}_{2}-\mathrm{SH}\right) \mathrm{H}^{+}=$ $635(40 \%)$ and (Df-NH-CH$) \mathrm{H}^{+}=603(100 \%)$.

\section{Preparation of Albumin-Desferal Conjugates (BSA-Df)}

To $2 \mathrm{~mL}$ of BSA solution $(20 \mathrm{mg}, 300 \mathrm{nmol}$ ) in phosphate buffer $(\mathrm{pH}=8.5,0.1 \mathrm{M}) 20 \mu \mathrm{L}$ of a freshly prepared SMCC solution in DMF $(150 \mathrm{mM}, 3 \mu \mathrm{mol})$ was added. After incubation for $30 \mathrm{~min}$ the protein was separated from the excess of SMCC by gel filtration using a PD-10 column pre-eluted with $0.1 \mathrm{M}$ phosphate buffer $(\mathrm{pH}$ $=6.5$ ). To the modified protein, $20 \mu \mathrm{L}$ of a freshly prepared SATA. Df solution in DMSO $(150 \mathrm{mM}, 3 \mu \mathrm{mol})$ and $20 \mu \mathrm{L}$ of freshly prepared hydroxylamine in phosphate $\mathrm{pH}=6.5(50 \mathrm{mg} / \mathrm{mL}, 30$ $\mu \mathrm{mol})$ were added. After $1 \mathrm{~h}$ at room temperature the excess of SATA-Df and hydroxylamine was removed with G-50 gel filtration.


BSA-Df-conjugate

SCHEME 1

The number of maleimide groups in the protein (before reaction with SATA-Df) was determined chemically using Ellman's reagent. For this purpose, $50 \mu \mathrm{L}$ of mercaptoethanol $(96.5 \mathrm{nmol}$ ) was added to $50 \mu \mathrm{L}$ of reaction mixture and diluted with $1.5 \mathrm{~mL}$ of phosphate buffer $(0.1 \mathrm{M}, \mathrm{pH}=8.5)$. Finally, $50 \mu \mathrm{L}$ of Ellman's reagent (4 $\mathrm{mg} / \mathrm{mL}$ ) was added. After $15 \mathrm{~min}$ of incubation at room temperature the UV-absorbance was measured at $412 \mathrm{~nm}$. Standards of mercaptoethanol from 0 to $100 \mathrm{nmol}$ were used for quantification. The protein concentration was detcrmincd using biorad protein assay (München, Germany) with BSA solutions $(0-0.5 \mathrm{mg} / \mathrm{mL}$ ) as standards.

Molecular-weight measurements were performed by matrixassisted laser desorption ionization mass spectrometry (MALDIMS) using a Finnigan MAT Vision 200 laser desorption time-offlight mass spectrometer (12).

\section{Labeling of BSA-Df with ${ }^{88} \mathrm{Zr}\left({ }^{88} \mathrm{Zr}\right.$-Df-BSA)}

The BSA-Df in $100 \mu \mathrm{L}$ of acetate $(0.1 \mathrm{M}, \mathrm{pH}=6)$ was added to freeze-dried ${ }^{88} \mathrm{Zr}$-oxalate (vide supra). The reaction mixture was analyzed by gel filtration (G-25, G-50, and HPLC) and ITLC. To optimize the labeling, the conditions were varied and the reaction mixtures were analyzed with ITLC. The time dependency of the labeling efficiency between $5 \mathrm{~min}$ and $2 \mathrm{~h}$ was examined. The influence of the protein concentration was determined using BSADf at $3,1,0.5,0.1$, and $0.05 \mathrm{mg} / \mathrm{mL}$. The labeling efficiency was determined after $1 \mathrm{~h}$ of incubation at room temperature.

\section{In Vitro Stability Studies}

The difference in stability of the protein-conjugate $(0.42 \mathrm{mg} / \mathrm{mL})$ obtained both by "direct" labeling or via Df was determined in citrate buffer of different concentrations $(0.167,1.67,16.7,167$, and 
$1670 \mathrm{mM}$ ). The percentage of ${ }^{88} \mathrm{Zr}$ attached to the protein was measured using gel filtration.

The in vitro stability of the $\mathrm{Zr}$-Df-conjugate was measured by incubation ${ }^{88} \mathrm{Zr}$-Df $(180 \mu \mathrm{M})$ or ${ }^{88} \mathrm{Zr}$-Df-BSA $(0.8 \mathrm{mg} / \mathrm{mL})$ in water, $0.8 \mathrm{mg} / \mathrm{mL}$ BSA, $20 \%$ human serum and $0.8 \mathrm{mM}$ citrate and subsequent analysis with TLC.

\section{Labeling of MSA with ${ }^{88} \mathrm{Zr}$}

MSA was used to investigate the in vivo behavior of ${ }^{88} \mathrm{Zr}$-labeled albumin and to investigate the dependence of the biodistribution on the modification grade. For these purposes MSA was modified in accordance with the BSA modification, but with different SMCC/ MSA ratio $(1.5,3,6$, and 10 , respectively). Labeling was performed for $1 \mathrm{~h}$ at protein concentrations of $3 \mathrm{mg} / \mathrm{mL}$ to maximize the yield, which were found to be above $90 \%$.

\section{Animal Distribution Measurements}

Animal experiments were carried out in accordance with the recommendations of the National Council on Animal Care and of the in-house Ethics Committee. Three different protocols were performed with female BALB/c mice of 6-7 weeks. When the animals were under anesthesia, labeled compounds $(100 \mu \mathrm{L}$ in $0.1 \mathrm{M}$ acetate, $\mathrm{pH}=7.0$ ) were administered in the retro-ocular plexus. At various intervals, mice were sacrificed and dissected. Tissues of interest were removed, weighed, and assayed for radinactivity. The percentage injected dose per gram tissue $(\% \mathrm{ID} / \mathrm{g})$ was calculated. Furthermore, the urine at the moment of sacrifice was collected and assayed for radioactivity.

To determine the biodistribution of free $\mathrm{Zr}$, sodium citrate $(0.4$ $\mathrm{mM}$ ) was added to frecze-dricd ${ }^{88} \mathrm{Zr}$-oxalate (vide supra). The ${ }^{88} \mathrm{Zr}$ solution $(14.4 \mu \mathrm{Ci})$ was injected and the tissue distribution was determined at $5 \mathrm{~min}, 4 \mathrm{~h}$, and $24 \mathrm{~h}$. The biodistribution of $\mathrm{Zr}$ - Df was determined as follows: A Df solution ( $10 \mathrm{mM}$ in acetate) was added to freeze-dried ${ }^{88} \mathrm{Zr}$-oxalate. After dilution to $0.75 \mathrm{mM} \mathrm{Df}, 12.3 \mu \mathrm{Ci}$ of ${ }^{8} \mathrm{Zr}$-Df complex was injected, and after 5,15 , and $30 \mathrm{~min}$ the biodistribution was determined. Biodistribution of the different ${ }^{88} \mathrm{Zr}$-Df-MSA conjugates (vide supra) was examined by injection of about $7-8 \mu \mathrm{Ci}(1-1.5 \mu \mathrm{g})$. After 1,4 , and $24 \mathrm{~h}$ the biodistribution was determined. As a control we also examined the biodistribution of ${ }^{123}$ I-labeled MSA $(94 \mu \mathrm{Ci}, 8.7 \mu \mathrm{g})$, labeled with the use of iodogen as described by Haisma et al. (8), at the same time-points in a parallel study.

\section{RESULTS \\ "Direct Labelling" of BSA with ${ }^{88} \mathrm{Zr}$}

In the presence of $0.1 \mathrm{M}$ acetate there was a variable amount (30-90\%) of ${ }^{88} \mathrm{Zr}$ co-migrating with BSA when analyzed by G-50 gel filtration (Fig. 1a). Besides the binding to the protein, a variable amount of ${ }^{88} \mathrm{Zr}$ remained associated to the column. In the presence of $0.1 \mathrm{M}$ citrate, no "direct labeling" of the protein and hardly any association to the column were observed. ITLC analysis of the reaction mixtures, in the presence of both acetate and citrate, showed little or no ${ }^{88} \mathrm{Zr}$ associated with the protein (Fig. 1b).

\section{Conjugation Chemistry and Labeling}

SATA-Df was synthesized in high yield (78\%). Maleimide groups were coupled to the albumin with SMCC (Scheme 1). The cou- pling yield was $50-60 \%$ (Ellman's reagent and mass spectroscopy, MS), which corresponded with five to six maleimide groups per albumin. About $10-20 \%$ of these maleimide groups reacted with SATA-Df as determined with MS, resulting in $0.5-1$ Df groups per protein. The remaining maleimide groups reacted with the excess of hydroxylamine, preventing further reaction with $\mathrm{SH}$ groups. This reduced the possibility for protein aggregate formation. During the modification steps there was no alteration in the HPLC pattern when compared to native albumin.

The labeling was performed by addition of the premodified albumin to freeze-dried ${ }^{88} \mathrm{Zr}$-oxalate. It was found that at increasing concentration of BSA-Df the labeling efficiency increased (Fig. 2). Under standard labeling conditions $(1 \mathrm{mg} / \mathrm{mL}, 1 \mathrm{~h})$ the ITLC and G-50 analyses (Fig. 1c,d) demonstrated a labeling efficiency of more than $90 \%$. The HPLC pattern of the reaction mixture showed that all radioactivity was co-migrated with the native albumin. To be sure of an efficient labeling, a labeling time of $1 \mathrm{~h}$ was used in further experiments, although it was found in the optimizing experiments that after $5 \mathrm{~min}$ the labeling efficiency did not increase (at protein concentration of $1 \mathrm{mg} / \mathrm{mL}$ ).

\section{Stability Studies}

Above citrate concentrations of $1.6 \mathrm{mM}, \mathrm{Zr}$ is transchelated from the "direct labeled" BSA ( $\mathrm{Zr}-\mathrm{BSA}$ ) to citrate (Fig. 3). In the case of $\mathrm{Zr}$-Df-BSA, hardly any $\mathrm{Zr}$-citrate was formed even at high citrate concentrations $(167 \mathrm{mM})$, demonstrating that the binding of ${ }^{88} \mathrm{Zr}$ via the bifunctional chelating agent Df is more stable toward citrate than that of directly bound ${ }^{88} \mathrm{Zr}$.

The $\mathrm{Zr}$-Df complex was incubated in several solutions of interest: citrate, BSA solution, and human serum, and subsequently the amount of $\mathrm{Zr}$ present in the $\mathrm{Zr}$-Df complex was measured using TLC. In all solutions less than $0.5 \%$ of the $\mathrm{Zr}$ was lost from the complex over $24 \mathrm{~h}$.

The stability of the binding between Df and the protein was investigated by storage of ${ }^{88} \mathrm{Zr}$-Df-BSA in the above-mentioned solutions and subsequent determination of the amount of ${ }^{88} \mathrm{Zr}$-Df using TLC. Over a 10-day period no loss of ${ }^{88} \mathrm{Zr}$-Df occurred in all solutions, indicating that the thioether binding between Df and BSA is stable in vitro.

\section{Biodistribution}

For a better understanding of the in vivo behavior of $\mathrm{Zr}$-labeled proteins, we also examined the biodistribution of ${ }^{88} \mathrm{Zr}$-citrate and ${ }^{88} \mathrm{Zr}$-Df. The blood clearance of the ${ }^{88} \mathrm{Zr}$-compounds was dependent on the chemical form of the ${ }^{88} \mathrm{Zr}$ (Fig. 4). $\mathrm{Zr}$-Df was cleared quickly from the circulation. After 5 min more than $23 \%$ of the injected dose was found in the urine. This fast glomerular excretion probably caused the temporary high kidney level. Uptake in other organs did not exceed $2 \%$ after $30 \mathrm{~min}$ (Table 1 ). The clearance of ${ }^{88} \mathrm{Zr}$-citrate was slower than that of the $\mathrm{Zr}$-Df complexes; after 4 and $24 \mathrm{~h}, 16.3$ and $3.0 \% \mathrm{ID} / \mathrm{g}$, respectively, were still present in the blood. The $\mathrm{Zr}$ was finally deposited in bone $(21 \% \mathrm{ID} / \mathrm{g}$ at $24 \mathrm{~h})$. The levels of $\mathrm{Zr}$ present in liver and kidney did not follow the clearance of the blood (Fig. 4), suggesting that $\mathrm{Zr}$ in these organs might be present in the intracellular species.

The biodistributions of ${ }^{88} \mathrm{Zr}$-Df-MSA and ${ }^{123} \mathrm{I}-\mathrm{MS} \Lambda$ are depicted in Fig. 5. The blood clearance of these conjugates was similar and significantly slower than those of $\mathrm{Zr}$-Df and $\mathrm{Zr}$-citrate (Fig. 4). The biodistribution of ${ }^{88} \mathrm{Zr}$-Df-MSA resembled that of ${ }^{123} \mathrm{I}$-MSA, 

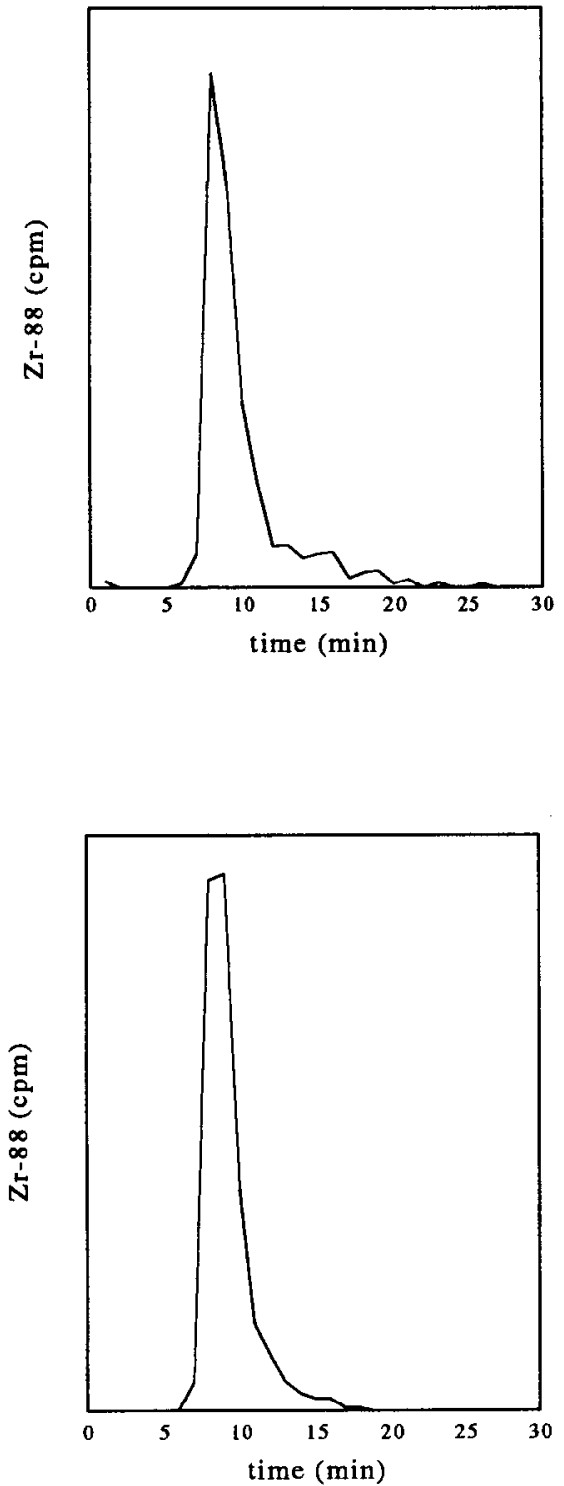

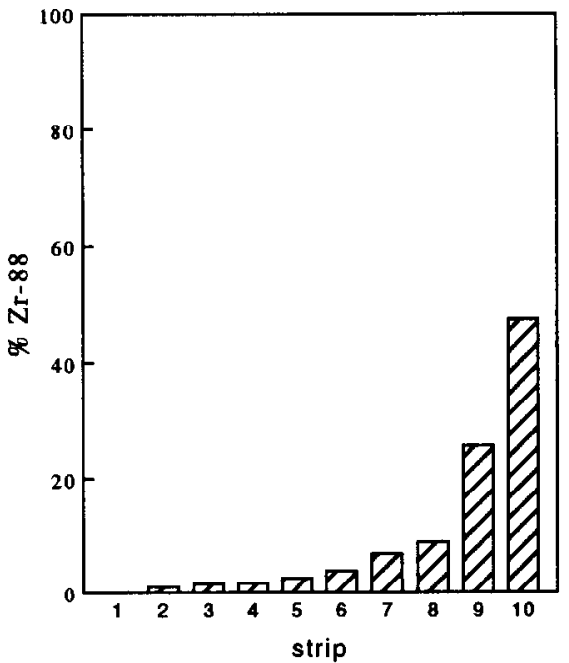

b

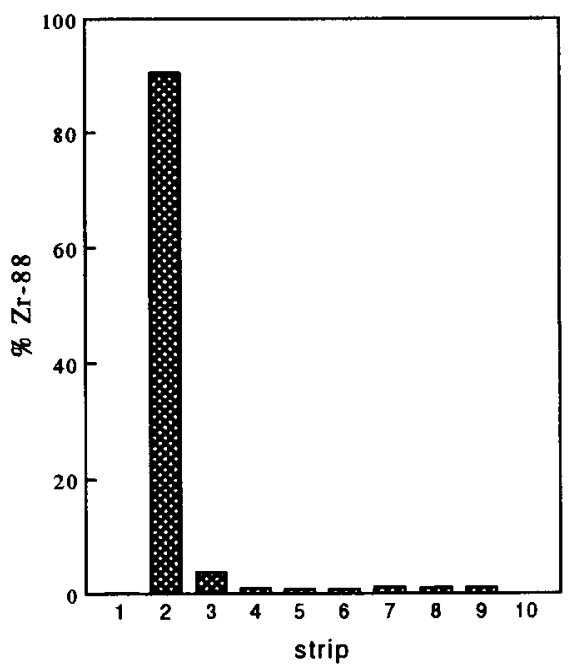

FIG. 1. The gel filtration profile and corresponding ITLC-pattern of BSA labeled with ${ }^{88} \mathrm{Zr}$ with the "direct" method (a,b) and via desferal $(c, d)$.

except for the uptake in liver, spleen, and kidneys, which was higher for ${ }^{88} \mathrm{Zr}$-Df-MSA. The amount of ${ }^{88} \mathrm{Zr}$ in these organs remained the same over the time period measured, whereas the amount of ${ }^{123} I$ decreased in time (Fig. 4). At higher SMCC/MSA ratio, the liver accumulation is higher and the kidney accumulation is lower (Fig. 6).

\section{DISCUSSION}

The physical characteristics of the positron emitter ${ }^{89} \mathrm{Zr}$ make it a good candidate for the labeling of proteins for various applications: for instance, to study the kinetics and biodistribution of proteins over a period of several days. Thus far, little effort has been made for labcling protcins with this isotope. The purpose of our study was to develop an efficient and practical method to label proteins with $\mathrm{Zr}$-isotopes, keeping in mind that the radioconjugate must be stable in vitro as well as in vivo and that the pharmacokinetic behavior must be conserved.

The most simple method for labeling proteins would be a direct labeling, making use of the chelating groups of the protein itself for complexation. Because $\mathrm{Zr}$ has a tendency to form complexes with a large variety of chelating agents and because it has been shown that $\mathrm{Zr}$ easily transchelates to proteins $(18,21)$, it seemed worthwhile to investigate such a direct method of labeling. Indeed, the results obtained with gel filtration indicated that simple addition of BSA to ${ }^{88} \mathrm{Zr}$ in the presence of acetate yielded a labeled protein (Fig. 1a). However, these results were not confirmed by ITLC analysis (Fig. 1b). This was thought to be caused by transchelation of $\mathrm{Zr}$ from the chelating groups of the protein to the citrate present in the eluent. This assumption was confirmed by the fact that, in the presence of $0.1 \mathrm{M}$ citrate, no labeling of BSA with ${ }^{88} \mathrm{Zr}$ was observed at all. The binding between the radiometal and the protein must be stable; 




FIG. 2. Efficiency of the labeling as function of the modified protein concentration.

therefore, owing to this in vitro instability, this direct labeling was rejected as a useful method. These results, however, showed that $\mathrm{Zr}$ has a tendency to bind nonspecifically to proteins.

An alternative for the labeling of proteins with $\mathrm{Zr}$-isotopes is the use of a bifunctional chelating agent. DeJesus and Nickels (3) have labeled polylysine with ${ }^{89} \mathrm{Zr}$, using DTPA. However, in earlier studies we found that $\mathrm{Zr}$-Df complexes are much more stable than $\mathrm{Zr}$-DTPA (23). This high stability of the $\mathrm{Zr}$-Df complexes was confirmed in the stability experiments performed in this study. In the presence of serum, albumin, and citrate, the $\mathrm{Zr}$ lost from the Df was less than $0.5 \%$ during a $24-\mathrm{h}$ period. Df, a nontoxic agent that is clinically used for reduction of iron plasma levels, has been used as a chelating agent for the labeling of proteins with Ga-isotopes. Incorporation of Df groups into proteins can be performed with the homofunctional agent glutaraldehyde $(26,29,40)$ and with heterofunctional agents like carbodiimides $(11,26)$. Because these agents have the tendency to form protein aggregates, Koizumi et al. (14) developed several other methods for coupling. With respect to the in vivo stability they found antibody conjugates linked by thioether bonds to be optimal. Such a method was also used by Arano et al. $(1,2)$ to couple Df via a metabolizable linker to antibodies. We have coupled Df to the protein via a thioetherbond. Maleimide groups were coupled to the protein using SMCC and reacted with SATA-Df (Scheme 1). The reaction conditions were mild, and with respect to the native protein no detectable increase in aggregation was observed by HPLC. No loss of Df was observed after several days of storage in different solutions (water, citrate, and albumin). Mass spectroscopy (MS) was used to quantitate the amount of incorporated maleimide and Df groups. The amount of maleimide groups (5-6 per BSA) determined with $\mathrm{MS}$ was in agree-

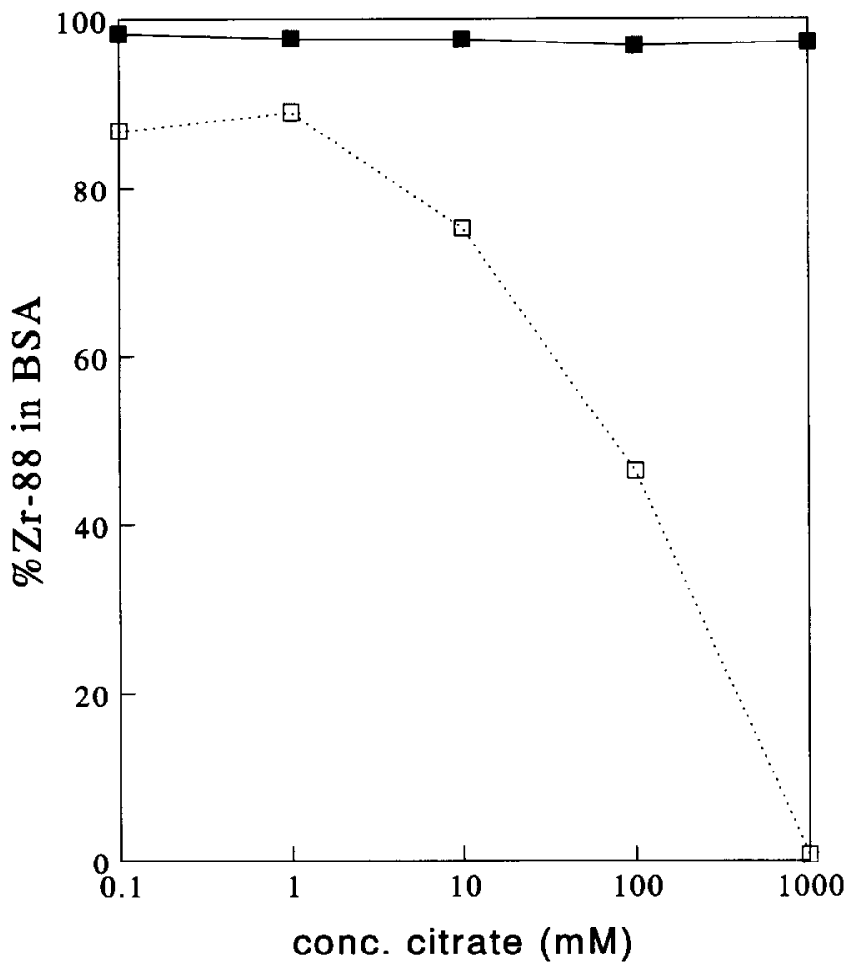

FIG. 3. Transchelation of ${ }^{88} \mathrm{Zr}$ from BSA (labeled with the "direct" method, $0.5 \mathrm{mg} / \mathrm{mL}, \square$ ) and ${ }^{88} \mathrm{Zr}$-Df-BSA (labeled via desferal, $0.5 \mathrm{mg} / \mathrm{mL}, \square$ ) to citrate at different concentrations.

ment with the results found with the chemical method using Ellman's reagent. An advantage of MS is that even samples of only 10 $\mu \mathrm{g}$ can easily be measured.

The labeling of Df-modified proteins with $\mathrm{Ga}$ isotopes has been discussed in the literature, but the use of Df to lahel proteins with $\mathrm{Zr}$ has not been described before. Both G-50 and ITLC analyses showed that simple addition of Df-modified protein (BSA-Df) to freeze-dried ${ }^{88} \mathrm{Zr}$-oxalate resulted in efficient labeling ( $>90 \%$, Fig. $1 \mathrm{c}, \mathrm{d})$. Furthermore, the modified protein can be prepared several weeks before actual usc; thus, this method of labeling might be convertible into a kit form. Because labeling with no carrier-added radioactive material follows pseudo first-order kinetics, the yield of labeling is only affected by the concentration of Df groups (Fig. 2).

A suitable method of labeling should not only be efficient and give stable conjugates, but the pharmacokinetical behavior of the protein must also be retained. To investigate whether our method of laheling alters the bindistribution of proteins we used the protein MSA (mouse serum albumin) as a model. This protein was used for its relative inertness in mice and because no immunological reactions were expected. Furthermore, owing to the fact that the amount of labeled MSA injected is negligible with respect to the amount of MSA already present in the mouse, concentration effects can be excluded.

To get an insight in the in vivo behavior of the radioconjugate, the biological properties of some degradable fragments such as free ${ }^{88} \mathrm{Zr}$ and ${ }^{88} \mathrm{Zr}$-Df were determined separately. $\mathrm{Zr}$-Df was cleared quickly from the circulation by the kidneys, a phenomenon that was also observed for Ga-Df complexes $(9,16),{ }^{88} \mathrm{Zr}$-citrate was used as source of free $\mathrm{Zr}$; the small amount of citrate with respect to the 

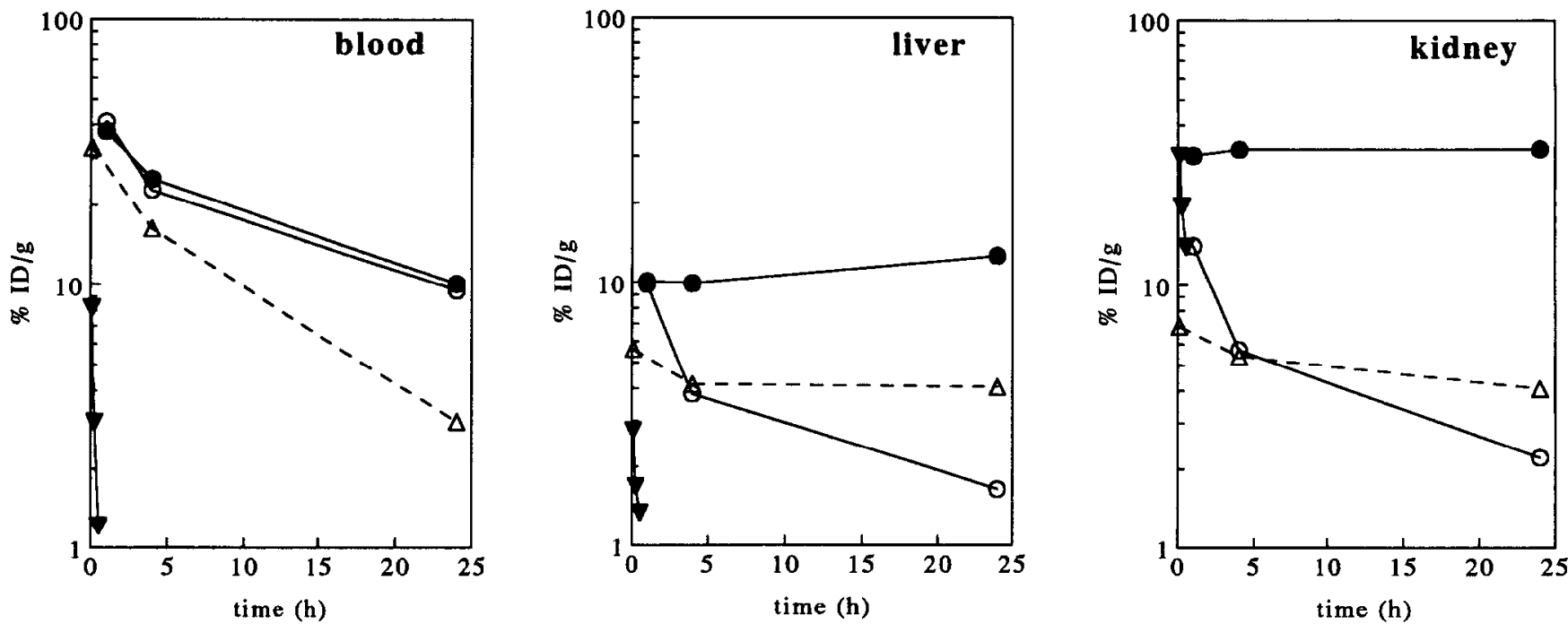

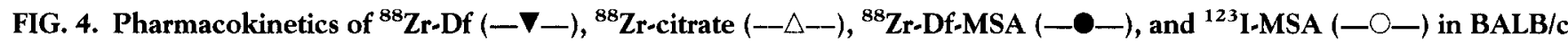
mice.

large amount of proteins in the plasma is neglectable. The ${ }^{88} \mathrm{Zr}$ remained longer in the circulation than did ${ }^{88} \mathrm{Zr}$-Df (Fig. 4) and was finally deposited in the bone (Table 1). The high bone accumulation is in agreement with results found by Shiraishi and Ichikawa (35) and Fletcher (5) and emphasizes the importance of a high stability of the conjugate. The similarity of the blood clearance of ${ }^{88} \mathrm{Zr}$-Df-MSA and ${ }^{123}$ I-MSA suggests the same rate of in vivo deg. radation of both conjugates (Figs. 4 and 5). The main differences between the biodistribution of ${ }^{88} \mathrm{Zr}$-Df-MSA and ${ }^{123}$ I-MSA are the higher accumulation of ${ }^{88} \mathrm{Zr}$ in the liver and kidneys.

Initially the amounts of ${ }^{123} \mathrm{I}$ and ${ }^{88} \mathrm{Zr}$ present in the liver were the same, but the amount of ${ }^{123}$ I rapidly decreased, whereas the amount of ${ }^{88} \mathrm{Zr}$ remained more or less constant (Figs. 4 and 5). Fast excretion of iodine from the liver and retention of radiometals in the liver is a well-known phenomena for radiolabeled antibodies $(10$, $15,34)$ and is attributed to trapping of the labeled catabolic products by liver cells $(4,6,27,28)$.

Activity found in the kidneys $( \pm 30 \% \mathrm{ID} / \mathrm{g})$ accounts for only $7 \%$ of the injected dose. This relatively high kidncy accumulation cannot be due to breakdown of the conjugate, resulting in a release of
${ }^{88} \mathrm{Zr}-\mathrm{Df}$, because this complex is rapidly excreted (Fig. 4). Therefore, it is more likely that the accumulation of $\mathrm{Zr}$ in the kidneys is, in analogy with antibody fragments labeled with radiometals (33, 36 ), the result of albumin degradation in this organ (19). The differences seen for $\mathrm{Zr}$ and I-labeled MSA are mainly restricted to a larger amount of $\mathrm{Zr}$ in the organs responsible for the protein degradation and a larger amount of iodine present in the stomach. These differences are probably caused by different behavior of the labeled catabolic product and are in accordance with differences in in vivo behavior found for In- and Ga-labeled proteins with respect to I-labeled proteins $(30,34)$. Therefore, it was suggested that the in vivo behavior of the albumin was hardly altered as a consequence of the labeling of the protein with ${ }^{88} \mathrm{Zr}$.

The influence of protein modification was determined by differing the amount of maleimide groups and, subsequently, the amount of Df groups. The larger the amount of modification, the larger the amount of $\mathrm{Zr}$ in liver and the lower the kidney accumulation (Fig. 6). A faster blood clearance and increase in liver accumulation as a result of overloading has also been shown for ${ }^{67} \mathrm{Cu}$ and ${ }^{99 \mathrm{~m}} \mathrm{Tc}$ labeled proteins in animals $(17,38)$ as well as in man $(39)$. This

TABLE 1. Distribution of ${ }^{88} \mathrm{Zr}$-Citrate and ${ }^{88} \mathrm{Zr}$-Df in BALB/c mice $(\mathrm{n}=3)$, represented as \%ID/g (SD)

\begin{tabular}{|c|c|c|c|c|c|c|}
\hline Tissue & \multicolumn{3}{|c|}{${ }^{88} \mathrm{Zr}$-citrate } & \multicolumn{3}{|c|}{${ }^{88} \mathrm{Zr}$-desferal } \\
\hline Blood & $32.88(5.29)$ & $16.28(1.01)$ & $3.03(1.22)$ & $8.18(1.35)$ & $3.04(0.92)$ & $1.21(0.34)$ \\
\hline Liver & $5.62(1.30)$ & $4.14(0.19)$ & $4.04(0.31)$ & $2.76(0.56)$ & $1.68(0.28)$ & $1.33(0.15)$ \\
\hline Spleen & $5.83(1.49)$ & $3.41(3.00)$ & $2.83(0.79)$ & $2.40(0.66)$ & $1.10(0.20)$ & $1.04(0.14)$ \\
\hline Kidney & $6.99(1.78)$ & $5.41(0.87)$ & $4.07(0.32)$ & $30.70(3.01)$ & $19.89(4.82)$ & $13.98(2.63)$ \\
\hline Muscle & $1.70(0.12)$ & $1.74(0.06)$ & $1.17(0.03)$ & $1.66(0.19)$ & $0.77(0.32)$ & $0.37(0.19)$ \\
\hline Lung & $12.07(1.86)$ & $5.92(1.43)$ & $3.14(1.13)$ & $5.31(0.83)$ & $2.23(0.52)$ & $1.14(0.28)$ \\
\hline Intestine & $3.96(0.14)$ & $1.66(0.31)$ & $0.96(0.31)$ & $1.93(0.14)$ & $1.32(0.35)$ & $1.21(0.92)$ \\
\hline Fat & $1.30(0.31)$ & $1.77(0.64)$ & $0.73(0.24)$ & $2.09(1.25)$ & $0.84(0.23)$ & $0.44(0.34)$ \\
\hline Skin & $1.56(0.72)$ & $4.53(0.39)$ & $2.34(0.32)$ & $3.93(0.40)$ & $2.47(0.77)$ & $1.21(0.49)$ \\
\hline
\end{tabular}




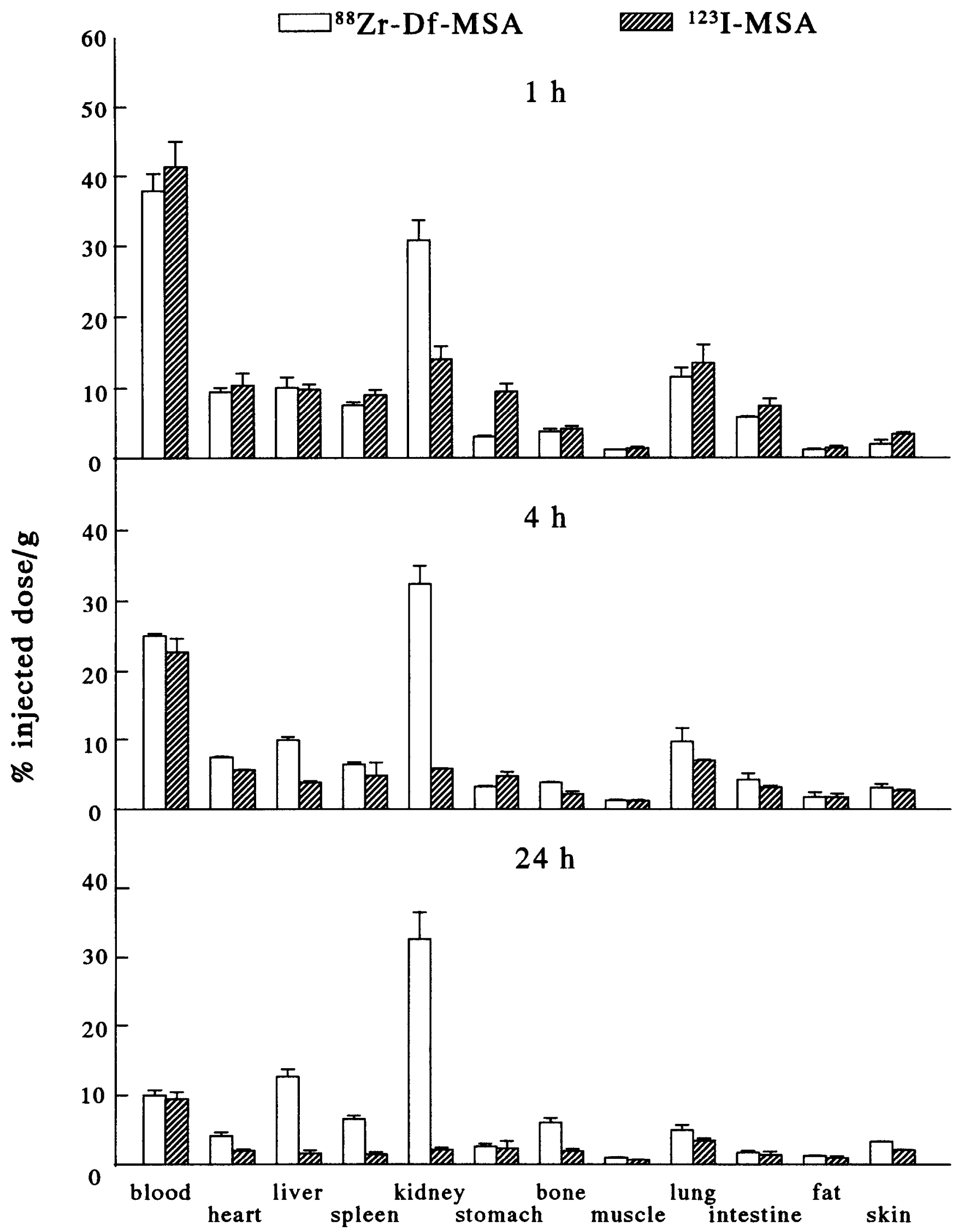

FIG. 5. Biodistribution of ${ }^{88} \mathrm{Zr}$-Df-MSA and ${ }^{123} \mathrm{~L}-\mathrm{MSA}$ in BALB/c mice $(n=3)$. 


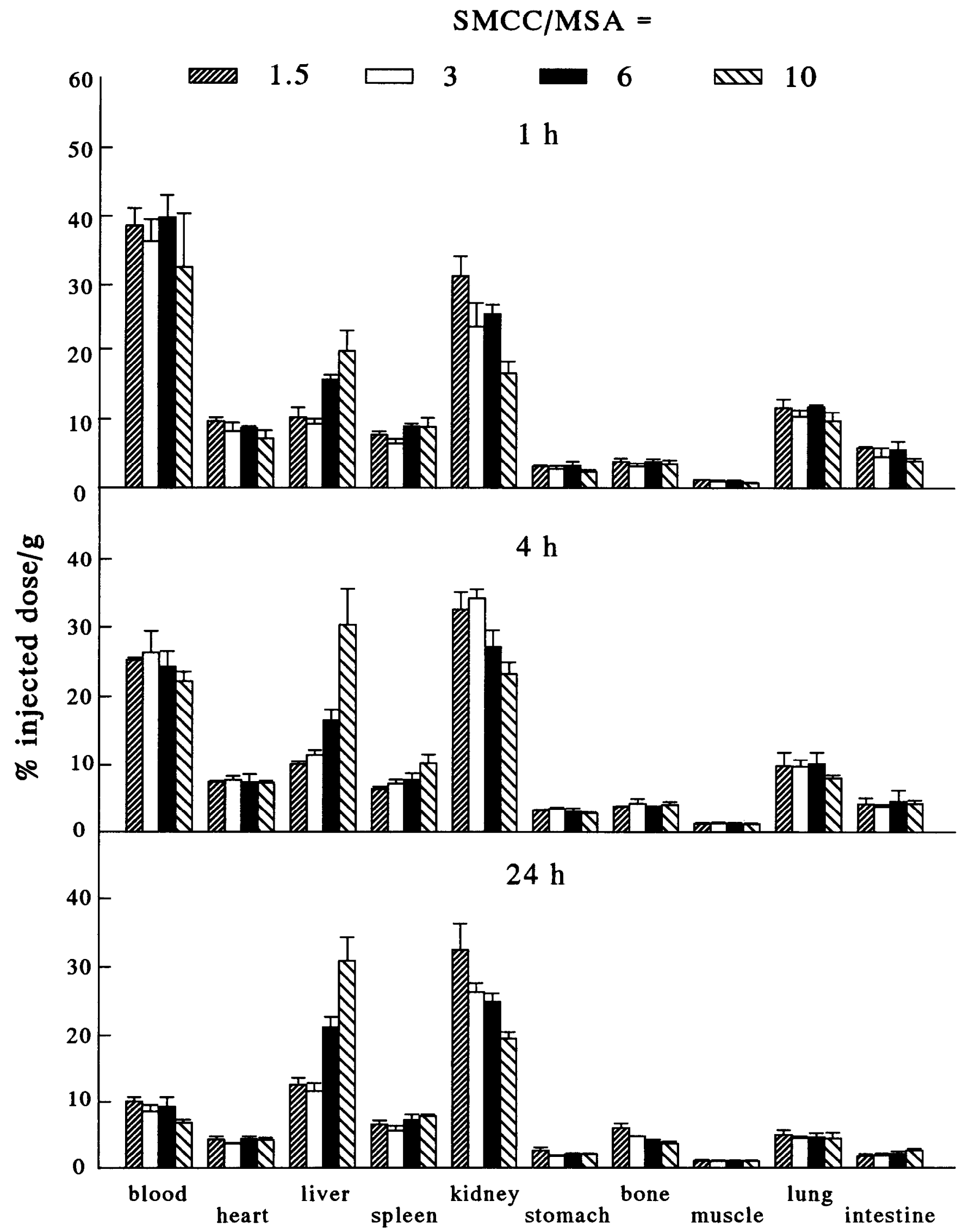

FIG. 6. Biodistribution in BALB/c mice $(n=3)$ of ${ }^{88} \mathrm{Zr}$-Df-MSA prepared with different SMCC/MSA ratios. 
implicates the preference of a small amount of chelating groups in the protein. Conversely, labeling efficiencies are directly related to the amount of chelating groups. Thus, for each protein the golden mean has to be found.

The amount of ${ }^{88} \mathrm{Zr}$ in bone after injection of ${ }^{88} \mathrm{Zr}$-Df-MSA hardly increased in time and is small when compared with the injection of ${ }^{88} \mathrm{Zr}$-citrate (Fig. 6). This can be an indication that the $\mathrm{Zr}$-Df-MSA conjugate is relatively stable.

In conclusion, we have shown that it is possible to label proteins with $\mathrm{Zr}$-isotopes. The conjugates have a high in vitro stability and a reasonable good in vivo stability, and they retain their in vivo behavior, as was shown for the model protein MSA.

The authors wish to thank G. W. M. Visser and G. A. M. S. van Dongen for their contribution to this report.

\section{References}

1. Arano Y., Inoue T., Mukai T., Wakisaka K., Sakahara H., Konishi J. and Yokoyama A. (1994b) Discriminated release of a hippurate-like radiometal chelate in nontarget tissues for target-selective radioactivity localization using $\mathrm{pH}$-dependent dissociation of reduced antibody. $J$. Nucl. Med. 35, 326-333.

2. Arano Y., Matsushima H., Tagawa M., Inoue T., Koizumi M., Hosono M., Sakahara H., Endo K., Konihi J. and Yokoyama A. (1994a) A newly designed radioimmuno conjugate releasing a hippurate-like radiometal chelate for enhanced target/nontarget radioactivity. Nucl. Med. Biol. $21,63-69$.

3. Dejesus O. T. and Nickles R. J. (1990) Production and purification of ${ }^{89} \mathrm{Lr}$, a potential PËI antibody label. Appl. Kadiat. Isot. 41, 789-790.

4. Duncan J. R. and Welch M. J. (1993) Intracellular metabolism of indium-111-DTPA labeled receptor targeted proteins. J. Nucl. Med. 34, 1728-1738.

5. Fletcher C. R. (1969) The radiological hazards of zirconium-95 and niobium-95. Health Phys. 16, 209-220.

6. Franano F. N., Edwards W. B., Welch M. J. and Duncan J. R. (1994) Metabolism of receptor-targeted ${ }^{111}$ In-DTPA-glycoproteins: Identification of ${ }^{111}$ In-DTPA- $\epsilon$-lysine as the primary metabolic and excretory product. Nucl. Med. Biol. 21, 1023-1034.

7. Garg P. K., Garg S. and Zalutsky M. R. (1991) Fluorine-18 labelling of monoclonal antihodies and fragments with preservation of immunoreactivity. Bioconjug. Chem. 2, 44-49.

8. Haisma H. J., Hilgers J. and Zurawski V. R. Jr. (1986) lodination of monoclonal antibodies for diagnosis and radiotherapy using a convenient one vial method. J. Nucl. Med. 27, 1890-1895.

9. Herscheid J. D. M., Isaacs H., de Jong R. B. J. and Hoekstra A. (1986) Evaluation of the renal scanning agent $N$-succinyldesferrioxamine $B$ in dogs. Eur. J. Nucl. Med. 11, 363-364.

10. Hnatowich D. J., Griffin T. W., Kosciuczyk C., Rusckowski M., Childs R. L., Mattis J. A., Shealy D. and Doherty P. W. (1985) Pharmacokinetics of an indium-111-labeled monoclonal antibody in cancer patients. J. Nucl. Med. 26, 849-858.

11. Janoki GY. A., Harwig J. F., Chanachai W. and Wolf W. (1983) $\left[{ }^{6 \pi} \mathrm{Ga}\right.$ a]desferrioxamine-HSA: Synthesis of chelon protein conjugates using carbodiimide as a coupling agent. Int. J. Appl. Radiat. Isot. 34, $871-8 \%$.

12. Jiménez C. R., van Veelen P. A., Li K. W., Wildering W. C., Geraerts W. P. M., Tjaden U. R. and van der Greef J. (1994) Neuropeptide expression and processing as revealed by direct matrix-assisted laser desorption ionization mass spectrometry of single neurons. J. Neurochem. 62, 404-407.

13. Kilbourn M. R., Dence C. S., Welch M. J. and Mathias C. J. (1987) Fluorine-18 labeling of proteins. J. Nucl. Med. 28, 462-470.

14. Koizumi M., Endo K., Kunimatsu M., Sakahara H., Nakashima T., Kawamura Y., Watanabe Y., Ohmomo Y., Arano Y., Yokoyama A. and Torizuka K. (1987) Preparation of ${ }^{67} \mathrm{Ga}$-labeled antibodies using deferoxamine as a bifunctional chelate: An improved method. J. Immunol. Methods 104, 93-102.

15. Koizumi M., Endo K., Watanabe Y., Saga T., Sakahara H., Konishi J., Yamamuro T. and Toyama S. (1989) Pharmacokinetics of internally laheled monoclonal antibodies as a gold standard: Comparison of bio- distribution of ${ }^{75} \mathrm{Se}-,{ }^{111} \mathrm{In}$-, and ${ }^{125} \mathrm{I}$-labeled monoclonal antibodies in osteogenic sarcoma xenografts in nude mice. Cancer Res. 49, 17521757.

16. Koizumi K., Tonami N. and Hisada K. (1982) Deferoxamine mesylate enhancement of ${ }^{67} \mathrm{Ga}$ tumor-to-blood ratios and tumor imaging. Eur. J Nucl. Med. 7, 229-233.

17. Kukis D. L., DeNardo G. L., DeNardo S. J., Mirick G. R., Miers L. A., Greiner D. P. and Meares C. F. (1995) Effect of extent of chelate substitution on the immunoreactivity and biodistribution of 2IT-BATLym-1 immunoconjugates. Cancer Res. 55, 878-884.

18. Link J. M., Krohn K. A., Eary J. F., Kishore R., Lewellen T. K., Johnson M. W., Badger C. C., Richter K. Y. and Nelp W. B. (1986) ${ }^{89} \mathrm{Zr}$ for antibody labeling and positron emission tomography. J. Label. Compds. Radiopharm. 23, 1297-1298 (Abstract).

19. Maunsbach A. B. (1969) Functions of lysosomes in kidney cells. In Lysosomes in Biology and Pathology (Edited by Dingle J. T. and Fell H. B.), pp. 115-154. North Holland Publishing, Amsterdam.

20. McPherson D. W., Umbricht G. and Knapp F. F. Jr. (1990) Radiolabeling of proteins with radioisotopes of copper using p-carboxyalkylphenylglyoxal bis $\left({ }^{4} \mathrm{~N}\right.$-methylthiosemicarbazone) (TSC) bifunctional chelates. J. Label. Compds. Radiopharm. 28, 877-899.

21. Mealey J. (1957) Turn-over of carrier-free zirconium-89 in man. Nature $179,673-674$.

22. Mease R. C., Meinken G. E., Lambert C., Steplewski Z. and Srivastava S. C. (1991) New ligands for labeling antibodies with cobalt for PET imaging. J. Nucl. Med. 32, 842 (Abstract).

23. Meijs W. E., Herscheid J. D. M., Haisma H. J. and Pinedo H. M. (1992) Evaluation of desferal as a bifunctional chelating agent for labeling antibodies with $\mathrm{Zr}$-89. Appl. Radiat. Isot. 43, 1443-1447.

24. Mcijs W. E., Herscheid J. D. M., Haisma H. J., Wijbrandts R., van Langevelde F., van Leuffen P. J., Mooy R. and Pinedo H. M. (1994) Production of highly pure no-carrier added ${ }^{89} \mathrm{Zr}$ for the labelling of antibodies with a positron enitter. Appl. Radiat. Isot. 45, 1142-1147.

25. Morphy J. R., Parker D. and Alexander R. (1988) Antibody labelling with functionalised cyclam macrocycles. J. Chem. Soc. Chem. Commun. 156-158.

26. Motta-Hennessy C., Eccles S. A., Dean C. and Coghlan G. (1985) Preparation of ${ }^{67} \mathrm{Ga}$-labelled human IgG and its Fab fragments using desferoxamine as chelating agent. Eur. J. Nucl. Med. 11, 240-245.

27. Motta-Hennessy C., Sharkey R. M. and Goldenberg D. M. (1990) Metabolism of indium-111-labeled murine monoclonal antibody in tumor and normal tissue of the athymic mouse. J. Nucl. Med. 31, 1510-1519.

28. Naruki Y., Carrasquillo J. A., Reynolds, J. C., Maloney P. J., Frincke J. M., Neumann R. D, and Larson S. M. (1990) Differential cellular catabolism of ${ }^{111} \mathrm{In},{ }^{90} \mathrm{Y}$ and ${ }^{125} \mathrm{I}$ radiolabeled T101 anti-CD5 monoclonal antibody. Nucl. Med. Biol. 17, 201-207.

29. Ohmomo Y., Yokoyama A., Suzuki J., Tanaka H., Yamamoto K., Horiuchi K., Ishii Y. and Torizuka K. (1982) ${ }^{67} \mathrm{Ga}$-labeled human fibrinogen: A new promising thrombus imaging agent. Eur. J. Nud. Med. 7, 458461.

30. Otsuka F. L., Fleischman J. B., and Welch M. J. (1986) Comparative studies using ${ }^{125} \mathrm{I}$ and ${ }^{111}$ In-labeled monoclonal antibodies. Nucl. Med. Biol. 13, 325-334.

31. Otsuka F. L., Welch M. J., Kilbourn M. R., Dence C. S., Dilley W. G. and Wells S. A. Jr. (1991) Antibody fragments labeled with fluorine-18 and gallium-68: In vivo comparison with indium-111 and todine-125. labeled fragments. Nucl. Med. Biol. 18, 813-816.

32. Parker D., Morphy J. R., Jankowski K. and Cox J. (1989) Implementation of macrocycle conjugated antibodies for tumour-targetting. Pure $\mathbb{E}^{2}$ Appl. Chem. 61, 1637-1641.

33. Pimm M. V. and Gribben S. J. (1994) Prevention of tenal tubule teabsorption of radiometal (indium-111) labelled Fab fragment of a monoclonal antibody in mice by systemic administration of lysine. Eur. J. Nucl. Med. 21, 663-665.

34. Ryser J. E., Jones R. M. L., Egeli R., Pélegrin A., Rose K., Kurt A. M., Perin M., Broquet P. E., Ambrosetti P., Fisch I., Pochon S., Donath A., Mach J. P. and Offord R. E. (1992) Colon carcinoma immunoscintigraphy by monoclonal anti-CEA antibody labeled with gallium-67. aminooxyacetyldeferroxamine. J. Nucl. Med. 33, 1766-1773.

35. Shiraishi $Y$. and Ichikawa R. (1972) Absorption and retention of ${ }^{144} \mathrm{Ce}$ and ${ }^{95} \mathrm{Zr}-{ }^{95} \mathrm{Nb}$ in newborn, juvenile and adult rats. Health Phys. 22, 373-378.

36. Smith A., Alberto R., Blaeuwenstein P., Novak-Hofer I., Maecke H. R. and Schubiger P. A. (1993) Preclinical evaluation of ${ }^{67} \mathrm{Cu}$-labeled in- 
tact and fragmentated anti-colon carcinoma monoclonal antibody Mab35. Cancer Res. 53, 5727-5733.

37. Srivastava S. C., Mausner L. F., Mease R. C., Kolsky K. L., Meinken G. E., Joshi V., Pyatt B., Wolf A. P., Schlyer D. J., Levy A. V. and Fowler J. S. (1993) Co-55-labeled monoclonal antibodies (MAbs) for tumor imaging with PET. J. Nucl. Med. 34, 237P (Abstract).

38. van Gog F. B., Visser G. W. M., Klok R., van der Schors R., Snow G. B. and van Dongen G.A.M.S. (1996) Monoclonal antibodies labeled with thenium-186 using the MAG3 chelate for clinical application: Relationship between the number of chelated groups and biodistribution characteristics. J. Nucl. Med. 37, 352-362.
39. Verbeke K. A., Van Hecke W. B., Mortelmans L. A. and Verbruggen A. M. (1994) First evaluation of technetium-99m dimercaptopropionyl albumin as a possible tracer agent for ventriculography in a volunteer. Eur. J. Nucl. Med. 21, 906-912.

40. Yokoyama A., Ohmomo Y., Horiuchi K., Saji H., Tanaka H., Yamamoto K., Ishii Y. and Torizuka K. (1982) Deferoxamine, a promising bifunctional chelating agent for labeling proteins with gallium: $\mathrm{Ga}-67$ DF-HSA: Concise communication. J. Nucl. Med. 23, 909-914.

41. Zweit J., Downey S. and Sharma H. L. (1991) Production of no-carrieradded zirconium-89 for positron emission tomography. Appl. Radiat. lsot. 42, 199-201. 